\title{
ETNOBOTANI OBAT PADA MASYARAKAT SUKU PENGULUH DI KPHP LIMAU UNIT VII HULU SAROLANGUN, JAMBI
}

\section{(Medicinal Ethnobotany of Penguluh Ethnic at The KPHP Limau Unit VII Hulu Sarolangun, Jambi)}

\author{
DiNi HARDiANI HAs ${ }^{1 *}$, ERviZAL A. M. ZUHUD ${ }^{2)}$ DAN AgUS HIKMAT ${ }^{2)}$ \\ 1) Program Studi Konservasi Biodiversitas Tropika, Sekolah Pasca Sarjana Institut Pertanian Bogor, Kampus \\ Darmaga, Bogor, Indonesia 16680 \\ 2) Departemen Konservasi Sumberdaya Hutan \& Ekowisata, Fakultas Kehutanan Institut Pertanian Bogor, Kampus \\ Darmaga, Bogor, Indonesia 16680
}

*Email: dinihas23@gmail.com

Diterima 30 Desember 2019 / Disetujui 13 April 2020

\begin{abstract}
The community of Penguluh (penguluh ethnic) is a local community that lives in the mountainous region of karts in Bukit Bulan, Limun Subdistrict, Sarolangun Regency. The plant utilization knowledge has been inherent in their societal culture as medicine, food, building materials and as also ritual material. The deterioration in tranditional treatment knowledge for younger generations is feared by loss of information regarding the utilization of herbs as medicine. The aim of the study was to identify the ethnobotanical medicine species of the plant by the people of the Penguluh and develop conservation strategy for development of medicinal species in the production forest area of Limau Unit VII Hulu at Sarolangun District Jambi. The study was conducted in December 2018 - January 2019. The ethnobotanical data was obtained through qualitative methods with data collection techniques through in-depth interviews. It was identified that 100 medicinal plant species utilized by the community to treat 33 types of disease. The species that have high ICS value indicate that these species play important role in community's lives towards healing the disease such as rambutan (Naphelium lappaceum), kasai (Pometia alnifolia), pisang kemali (Musa balbisiana), Kates (Carica papaya) dan pinang (Areca catechu). Conservation strategies in the development of plant herbs can be done by: (1) maximize the use of herbal medicines that can be done by a) intensive training in the processing of herbal medicine into a product that is ready to use by KPHP, B) involvement the notable local college's role in dosage arrangement of herbal medicines that accelerate healing c) local governments involvement in marketing penetration of existing plant medicine so the community easily sell the medicine (2) cultivation development and models of utilization that are not disturb the populations (3) the development of traditional medicine to be potential economic value.
\end{abstract}

Keywords: Conservation strategies, Ethnobotany, Medicinal herbs, Penguluh, Traditional knowledge

\section{ABSTRAK}

Masyarakat Suku Penguluh merupakan masyarakat lokal yang tinggal di kawasan pegunungan karst di daerah Bukit Bulan, Kecamatan Limun, Kabupaten Sarolangun. Pengetahuan pemanfaatan tumbuhan telah melekat dalam kebudayaan masyarakat sebagai obat, pangan, bahan bangunan dan sebagai bahan ritual. Penurunan pengetahuan pengobatan secara trandisional bagi generasi muda dikhawatirkan menyebabkan hilangnya informasi mengenai pemanfaatan tumbuhan sebagai obat. Tujuan dari penelitian ini adalah mengidentifikasi etnobotani spesies tumbuhan obat oleh masyarakat Suku Penguluh serta menyusun strategi konservasi dalam pengembangan spesies tumbuhan obat di kawasan hutan produksi KPH Limau Unit VII Hulu di Kabupaten Sarolangun Jambi. Penelitian dilaksanakan pada bulan Desember 2018 - Januari 2019. Data etnobotani diperoleh melalui metode kualitatif dengan teknik pengumpulan data wawancara mendalam. Tercatat 100 spesies tumbuhan obat yang dimanfaatkan oleh masyarakat untuk mengobati 33 jenis penyakit. Spesies yang memiliki nilai ICS yang tinggi mengidentifikasikan bahwa spesies tersebut sangat berperan dalam kehidupan masyarakat terhadap penyembuhan penyakit yaitu rambutan (Naphelium lappaceum), kasai (Pometia alnifolia), pisang kemali (Musa balbisiana), Kates (Carica papaya) dan pinang (Areca catechu). Strategi konservasi dalam pengembangan tumbuhan tumbuhan obat dapat dilakukan dengan cara : (1) Memaksimalkan pemakaian obat herbal yaitu dapat dilakukan dengan: a) Membuat pelatihan dalam mengolah obat herbal menjadi sebuah produk yang siap pakai oleh pihak KPHP, b) Pengaturan dosis obat herbal yang mempercepat penyembuhan oleh perguruan tinggi, c) Pemasaran tumbuhan obat yang sudah ada sehingga masyarakat mudah menjualnya oleh pemerintah daerah; (2) Pengembangan budidaya dan model-model pemanfaatan yang tidak mengganggu populasi; (3) Pengembangan obat tradisional menjadi nilai ekonomi.

Kata kunci: etnobotani, pengetahuan tradisional, strategi konservasi, suku penguluh, tumbuhan obat

\section{PENDAHULUAN}

Masyarakat lokal yang berada di Provinsi Jambi telah memanfaatkan tumbuhan sebagai obat salah satunya adalah Suku Penguluh. Masyarakat Suku Penguluh merupakan masyarakat lokal yang tinggal di kawasan pengunungan karst daerah Bukit Bulan,
Kecamatan Limun, Kabupaten Sarolangun. Suku Penguluh merupakan salah satu masyarakat yang sangat menggantungkan hidupnya dengan sumber daya alam yang ada di hutan, mereka mencari dan mengumpulkan makanan didalam hutan sehingga hutan menjadi jantung bagi keberlangsungan hidup mereka, tidak hanya memiliki nilai ekonomi saja tetapi memiliki nilai adat 
yang tinggi juga (Ibramim et al. 2013). Tradisi pengobatan suatu masyarakat tidak terlepas dari kaitan budaya setempat. Persepsi sehat dan keragaman spesies tumbuhan yang digunakan sebagai obat tradisional terbentuk melalui proses sosialisasi yang secara turun temurun di percaya dan diyakini kebenarannya (Rahayu et al. 2014).

Pengetahuan etnobotani banyak ditemukan dalam suku-suku tradisional di Indonesia yang merupakan hasil dari berintraksi dan melakukan pemanfaatan tumbuhan hutan. Berbagai penelitian etnobotani yang dilakukan oleh LIPI telah diketahui paling tidak ada 78 spesies tumbuhan obat yang digunakan oleh 34 etnis untuk mengobati penyakit malaria, 133 spesies tumbuhan obat yang digunakan untuk penyakit demam oleh 30 etnis dan 98 spesies tumbuhan obat yang digunakan untuk penyakit kulit oleh 27 etnis (Zuhud 2008).

Salah satu permasalahan konservasi tumbuhan obat adalah punahnya budaya dan pengetahuan tradisional penduduk lokal di dalam atau di sekitar hutan. Masyarakat Suku Penguluh merupakan salah satu masyarakat lokal yang memiliki pengetahuan tradisional mengenai etnobotani tumbuhan obat sehingga diperlukannya dokumentasi melalui penelitian. Penurunan pengetahuan pengobatan secara tradisional bagi generasi muda dikhawatirkan menyebabkan hilangnya informasi mengenai pemanfaatan tumbuhan sebagai obat. Pada penelitian Salsabila et al. (2014) pengetahuan tentang tumbuhan obat sebesar 49,31\% pada responden dewasa madya yang berusia 41-65 dan menurun pada responden dewasa awal (20-40 tahun) sebesar 32,88\% dan remaja (15-19 tahun) sebesar 2,74\%. Kondisi tersebut dikhawatiran akan cenderung mengikis praktek kearifan tradisional. Keterisolasian yang terbuka juga mempercepat pembangunan ekonomi masyarakat dan pada akhirnya berakibat terhadap pemanfaatan sumberdaya yang semakin intensif dan menjadi tidak terkendali (Pattiselano et al. 2015). Berdasarkan latarbelakang tersebut, tujuan penelitian adalah mengidentifikasi etnobotani obat yang dimanfaatkan oleh masyarakat Suku Penguluh dan menyusun strategi dalam pengembangan tumbuhan obat di kawasan hutan produksi KPHP Limau Unit VII Hulu di Kabupaten Sarolangun Jambi.

\section{METODE PENELITIAN}

Penelitian dilaksanakan bulan Desember 2018 Januari 2019 pada masyarakat Suku Penguluh di kawasan hutan produksi Kesatuan Pengelolaan Hutan Produksi (KPHP) Limau Unit VII Hulu Kabupaten Sarolangun Provinsi Jambi. Lokasi penelitian terdiri dari tiga desa yaitu Desa Napal Melintang, Meribung dan Mersip, sedangkan Desa Temalang tidak dipilih karena memiliki jarak yang jauh dari ketiga desa lainya. Alat yang digunakan adalah kamera dan kuesioner untuk wawancara. Data karakteristik responden yaitu jenis kelamin, usia, pendidikan dan mata pencaharian, dan etnografi suku penguluh. Data etnobotani atau pemanfaatan tumbuhan obat oleh masyarakat dengan variabel yaitu nama spesies, tipe habitat, habitus, status budidaya, tujuan penggunaan, cara pengelolaan dan cara pemakaian. Teknik pengumpulan data etnobotani melalui wawancara mendalam (in-depth interview) terhadap informan terkait spesies tumbuhan obat yang dimanfaatkan masyarakat Suku Penguluh dengan teknik snowball sampling dengan informan kunci adalah kepala desa. Teknik snowball sampling yaitu teknik memilih responden-responden yang mempunyai karakteristik terkait dengan tujuan penilitian dan responden tambahan yang ditujukkan oleh responden sebelumnya (Sarwono 2006).

Analisis pengelolaan data hasil wawancara responden dan etnobotani obat disajikan dalam bentuk persentase. Analisis terhadap indeks penting budidaya (Indeks of Cultural Significance) merujuk pada Turner (1988). Analisis ini bertujuan untuk mengevaluasi atau mengukur kepentingan satu spesies tumbuhan bagi kehidupan masyarakat lokal. Metode ini selanjutnya dikembangkan oleh Purwanto (2002) yang meliputi tiga komponen penilaian yakni :

1. Kualitas Penggunaan (quality of use)

Kualitas penggunaan merupakan variasi dari berbagai sifat penggunaan spesies tumbuhan dengan memberikan penilaian sebagai berikut :

- $\quad$ Nilai 5 = bahan makanan utama;

- $\quad$ Nilai 4 = makanan sekunder;

- Nilai 3 = makanan lainnya + bahan sekunder dan bahan obat tradisional.;

- $\quad$ Nilai 2 = bahan ritual, mitos dan rekreasi;

- $\quad$ Nilai 1 = tumbuhan yang dikenal namun tidak digunakan secara khusus hanya diketahui kegunaannya saja.

2. Intensitas Penggunaan (intensity of use).

Penilaian intensitas penggunaan didasari oleh pengaruh penggunaan spesies tumbuhan dalam kehidupan sehari-hari dalam suatu masyarakat. Katagori penilaian sebagai berikut :

- $\quad$ Nilai 5 = intensitas sangat tinggi (very high intensity)

- $\quad$ Nilai 4 = nilai intensitas penggunaan cukup tinggi (moderately high use intensity)

- $\quad$ Nilai 3 = intensitas penggunaan sedang (medium use intensity)

- $\quad$ Nilai 2 = intensitas penggunaan rendah (low use intensity)

- $\quad$ Nilai 1 = intensitas penggunaan sedikit (minimal use intensity)

3. Eksklusivitas Penggunaan (Excusivity use intensity) Penilaian eksklusivitas penggunaan spesies tumbuhan didasari oleh tingkat rasa lebih disenangi atau lebih disukai (prefrensi), yakni :

- $\quad$ Nilai 2 = spesies tumbuhan yang paling disukai dan merupakan pilihan utama dan tidak dapat digantikan 
- Nilai 1 = terdapat beberapa spesies yang ada kemungkinan menjadi pilihan

- $\quad$ Nilai 0,5 = sumber skunder dengan eksklusifitas Nilai indeks penting budaya menggunakan persamaan sebagai berikut :

$$
\mathrm{ICS}=\sum_{\mathrm{i}=1}^{\mathrm{n}}\left(\mathrm{q}_{\mathrm{i}} \times \mathrm{i}_{\mathrm{i}} \times \mathrm{e}_{\mathrm{i}}\right) \mathrm{ni}
$$

Keterangan : ICS = Indeks kepentingan budaya; $q_{i}=$ nilai kualitas; $\mathrm{i}_{\mathrm{i}}=$ nilai intensitas; $\mathrm{e}_{\mathrm{i}}=$ nilai eksklusivitas

ICS menunjukan persamaan jumlah nilai guna suatu spesies tumbuhan obat dari pemanfaatan ke-satu (i) hingga ke-n. Nilai kegunaan ditentukan memberi skor atau nilai kualitas suatu spesies tumbuhan obat, nilai intensitas (intensity value) menggambarkan intensitas pemanfaatan spesies tumbuhan obat dan nilai eksklusivitas (exclusivity value) merupakan tingkat kesukaan spesies tumbuhan obat. Skala kategori nilai ICS ditentukan berdasar nilai pemanfaatan setiap spesies tumbuhan obat menggunakan Tabel 1.

Tabel 1 Skala katagori nilai ICS

\begin{tabular}{cccc}
\hline Skor & Kisaran nilai ICS & Katagori & Kode \\
\hline 3 & $43-62$ & Tinggi & T \\
2 & $23-42$ & Sedang & SD \\
1 & $3-22$ & Rendah & R \\
\hline
\end{tabular}

\section{HASIL DAN PEMBAHASAN}

\section{Etnografi Suku Penguluh}

Masyarakat Suku Penguluh daerah bukit bulan merupakan salah satu Suku Melayu yang berasal dari Sumatera Barat yang berada di Kecamatan Limun, Kabupaten Sarolangun Provinsi Jambi. Jumlah penduduk Kecamatan Limun berjumlah 17.212 jiwa. Perbandingan laki-laki berjumlah 8.651 jiwa dan perempuan berjumlah 8.561 jiwa. Suku Penguluh bukit bulan berada pada empat desa yaitu Desa Napal Melintang, Desa Meribung, Desa Mersip dan Desa Temalang (Tabel 2).

Tabel 2 Jumlah penduduk setiap desa.

\begin{tabular}{lc}
\hline \multicolumn{1}{c}{ Nama desa } & Jumlah penduduk (jiwa) \\
\hline Desa Napal Melintang & 826 \\
Desa Mersip & 917 \\
Desa Meribung & 957 \\
Desa Temalang & 259 \\
\hline
\end{tabular}

Bahasa yang digunakan oleh masyarakat Suku Penguluh umumnya adalah bahasa melayu jambi dengan dialek padang. Sistem mata pencaharian suku penguluh marga bukit bulan terbagi menjadi empat yaitu bertani, berkebun, mendulang emas, berdagang sembako, pemungut hasil hutan non kayu (buah, madu, rotan, pandan dan rumbai-rumbai). Sistem teknologi mayoritas masyarakat Suku Penguluh dalam bertani masih tradisional menggunakan cangkul dalam menggemburkan tanah sebelum menanam padi.
Pengelolaan hasil perkebunan seperti tebu menjadi air tebu menggunakan alat yang dibuat langsung oleh masyarakat, sedangkan pengelolaan hasil hutan seperti buah kepayang menjadi minyak menggunakan alat dari pihak KPHP.

Asal mula dan sejarah Suku Penguluh berawal pada abad ke-13 s/d 14 Masehi kawasan Bukit Bulan didatangi oleh perantau dari Kerajaan Pangaruyung yang bernama Datuk Mangkuto Alam. Datuk Mangkuto Alam melihat sebuah cahaya yang sangat terang seperti bulan yang keluar dari bukit, kemudian mencari tahu asal dari cahaya tersebut, beliau berjalan menyusuri sungai dan tibalah di suatu bukit kapur yang merupakan asal dari cahaya yang dilihat dari Pangaruyung. Datuk Mangkuto Alam memutuskan untuk tinggal di bukit tersebut yang sekarang disebut dengan Desa Napal Melintang. Desa Napal Melintang juga dipercaya sebagai desa tertua kemudian muncul desa yang lain yaitu Desa Meribung, Temalang, Mersip dan Lubuk Bedorong. Mayoritas kepercayaan Suku Penguluh marga bukit bulan adalah beragama Islam. Desa Lubuk Bedorong mayoritas agamanya adalah Islam, namun terdapat beberapa masyarakat Suku Anak Dalam (SAD) yang beragama Kristen. Suku Penguluh terdapat beberapa kepercayaan dalam mengelola sumber daya alam yang sudah ada pada zaman nenek moyang yang diwariskan secara turuntemurun.

\section{Karakteristik Responden}

Hasil wawancara terhadap 46 responden yang terdiri dari tiga desa yaitu Desa Napal Melintang, Mersip dan Meribung menunjukan bahwa responden berjenis kelamin laki-laki (55\%) lebih banyak dibandingkan responden perempuan (45\%). Pengetahuan dan pemanfaatan tumbuhan sebagai obat diwariskan secara turun-temurun oleh nenek moyang. Hal ini terlihat dari hasil wawancara yang menunjukkan responden usia $\geq 65$ tahun memiliki tingkat pengetahuan yang lebih besar sebesar $61 \%$, sedangkan responden yang berusia 36-45 tahun memiliki pengetahuan yang kecil sebesar $2 \%$. Menurut Salsabila at al. (2014) responden yang berusia 41-65 tahun memiliki banyak informasi tentang tumbuhan obat dan obat, hal ini karena dalam kehidupan sehari-hari mereka menggunakan dan memanfaatkan tumbuhan pangan dan obat secara langsung. Tingkatan pendidikan masyarakat Suku Penguluh yang mengetahui dan menggunakan tumbuhan obat didominasi oleh tingkat pendidikan Sekolah Dasar (SD) yang berusia $\geq 46$ tahun dan Sekolah Rakyat (SR) didominasi oleh responden yang berusia $\geq 65$ tahun $(41 \%)$. Hal ini karena terbatasnya sarana dan prasarana pendidikan serta aksesibilitas yang mengakibatkan para responden yang berusia $\geq 46$ tahun hanya sebatas tamatan SD. Sedangkan responden yang berusia berusia $\geq 65$ tahun hanya sebatas tamatan SR. Menurut Utami at al. (2019) tingkat pendidikan tidak mempengaruhi secara signifikan terhadap pengetahuan tumbuhan obat yang dimiliki responden karena tidak mengurangi kemampuan 
masyarakat dalam meramu tumbuhan obat disebabkan pengaruh tradisi turun-temurun dari orang tua.

Mayoritas masyarakat Suku Penguluh bekerja sebagai petani (93\%). LPHD dan LPHA berperan dalam melestarikan hutan dengan cara mengontrol hutan secara rutin, sehingga kelestarian hutan dapat terjaga.

\section{Etnobotani Tumbuhan Obat}

Berdasarkan hasil penelitian yang dilakukan pada Masyarakat Suku Penguluh, didapatkan beberapa bentuk pemanfaatan dan pengelolaan, bagian tumbuhan yang dimanfaatkan oleh masyarakat. Tercatat 100 spesies tumbuhan obat yang terdapat di tepi sungai, sawah, ladang, hutan dan pekarangan. Terdapat 51 spesies tumbuhan budidaya dan 49 spesies tumbuhan liar. Masyarakat lebih banyak memanfaatkan tumbuhan herba baik yang liar maupun budidaya yang terdapat di dalam hutan serta pekarangan masyarakat. Coku (Kaempfreria galanga), kunyit bolai (Zingiber purpureum), kunyit (Curcuma longa), lengkuas (Alpinia galanga), setawa muda (Costus speciosus), kenidai (Pterospermum javanicum). Tumbuhan herba yang dimanfaatkan didominasi oleh famili Zingiberaceae. Menurut Auliani et al. (2014) famili Zingiberaceae merupakan salah stau famili yang dimanfaatkan oleh masyarakat di Kecamatan Siak Hulu dalam pengobatan disamping sebagai bahan kebutuhan sehari-hari. Pemanfaatan tumbuhan dari famili Zingiberaceae oleh masyarakat telah dikenal oleh masyarakat luas yang pemanfaatannya sudah dari zaman dulu hingga sekarang dalam bidang pengobatan.

Bagian tumbuhan yang banyak dimanfaatkan oleh masyarakat adalah bagian daun (Tabel 3). Bagian daun banyak dimanfaatkan oleh masyarakat kerena pemanenan yang mudah dan tidak merusak pertumbuhan tanaman. Menurut Jalius dan Muswita (2013) bagian organ tumbuhan yang banyak digunakan masyarakat Batin adalah organ daun, hal ini karena penggunaan obat luar yang dilakukan oleh masyarakat umumnya menggunakan organ yang mudah dihancurkan serta organ daun lebih mudah digunakan untuk mengambil sari atau khasiat yang dimiliki tumbuhan tersebut.
Cara pengelolaan tumbuhan obat oleh masyarakat umumnya dengan cara direbus yang digunakan untuk penyakit gatal-gatal, sesak nafas, menyegarkan badan, penambah darah dan ramuan pra dan pasca melahirkan. Sedangkan cara pemakaian dengan cara diminum sering dilakukan oleh masyarakat terutama pada wanita pasca melahirkan, hal ini bertujuan untuk penambah darah dan membersihkan bagian dalam perut selepas melahirkan.

\section{Klasifikasi Penyakit}

Berdasarkan wawancara terhadap masyarakat, terdapat 100 spesies tumbuhan obat yang digunakan untuk mengobati 32 kelompok penyakit yang diderita oleh masyarakat Suku Penguluh (Gambar 1). Manfaat tumbuhan obat yang paling banyak adalah sebagai penyembuh penyakit demam sebanyak 18 spesies dari berbagai bagian tumbuhan yang dimanfaatkan. Cara pengolahan tumbuhan obat oleh masayarakat Suku Penguluh terbagi menjadi 21 cara pengolahan yaitu direbus, diremas, dipanggang, ditumbuk, langsung diminum, dikunyah, direndam, dipotong, diparut, ditumbuk lalu direbus, direndam lalu diremas, diseduh, dicincang, dicincang lalu dimasak, dicincang lalu dipanggang, dipanggang lalu dihaluskan dan diperas langsung. Sedangkan cara pemakaian tumbuhan obat oleh masyarakat Suku Penguluh dibagi menjadi 13 cara pemakaian yaitu diminum, ditempelkan, diusapkan, dioleskan, dimandikan, dimakan, diasapi, dibalutkan, digosok, diteteskan, diurut, direndam dan disemburkan.

Beberapa contoh spesies tumbuhan yang digunakan sebagai penyembuh penyakit demam yaitu rambutan (Naphelium lappaceum), durian (Durio zibethinus), kasai (Pometia alnifolia), kapas (Ceiba pentandra), selasi (Ocimum basilicum), patah mudi (Emilia sonchhifolia), kemuning (Murraya paniculata), pua angik (Alpinia aquatica), akar bulu pucuk lima (Vitis polystachya), bunga raya (Hibiscus rosa-sinensis), pisang kemali (Musa balbisiana), sonam (Argostemma montanum).

Tabel 3 Bagian tumbuhan yang dimanfaatkan.

\begin{tabular}{clcc}
\hline No & Bagian tumbuhan & Jumlah & Persentase $(\%)$ \\
\hline 1 & Daun & 60 & 53,1 \\
2 & Buah & 11 & 9,7 \\
3 & Akar & 10 & 8,8 \\
4 & Batang & 9 & 8,0 \\
5 & Kulit & 7 & 6,2 \\
6 & Rimpang & 6 & 5,3 \\
7 & Umbut & 3 & 2,7 \\
8 & Umbi & 2 & 1,8 \\
9 & Getah & 2 & 1,8 \\
10 & Tunas & 1 & 0,9 \\
11 & Biji & 1 & 0,9 \\
12 & Bunga & 1 & 0,9 \\
\hline
\end{tabular}




\section{Manfaat Tumbuhan Obat}

Tumbuhan yang dimanfaatkan oleh masyarakat Suku Penguluh memiliki khasiat obat dalam penyembuhan maupun pencegahan penyakit. Pengertian berkhasiat obat adalah mengandung zat aktif yang berfungsi mengobati penyakit tertentu atau jika tidak mengandung zat aktif tertentu tapi mengandung efek resultan/sinergi dari berbagai zat yang berfungsi mengobati (Djauhariya dan Hernani 2004). Tumbuhan yang digunakan oleh Masyarakat Suku Penguluh berkhasiat menyembuhkan beberapa penyakit yang diderita masyarakat (Tabel 4).

\section{Index Cultural Significanse (ICS)}

Angka hasil perhitungan ICS menunjukan tingkat kepentingan setiap jenis tumbuhan bermanfaat oleh masyarakat. Berdasarkan hasil analisis data tumbuhan yang dimanfaatkan pada masyarakat Suku Penguluh diperoleh hasil nilai ICS (Tabel 5). Berdasarkan hasil perhitungan nilai ICS terdapat lima spesies tumbuhan yang memiliki hasil perhitungan yang tinggi yaitu rambutan (Naphelium lappaceum), kasai (Pometia alnifolia), kates (Carica papaya), pinang (Areca catechu) dan pisang kemali (Musa balbisiana) (Tabel 6).

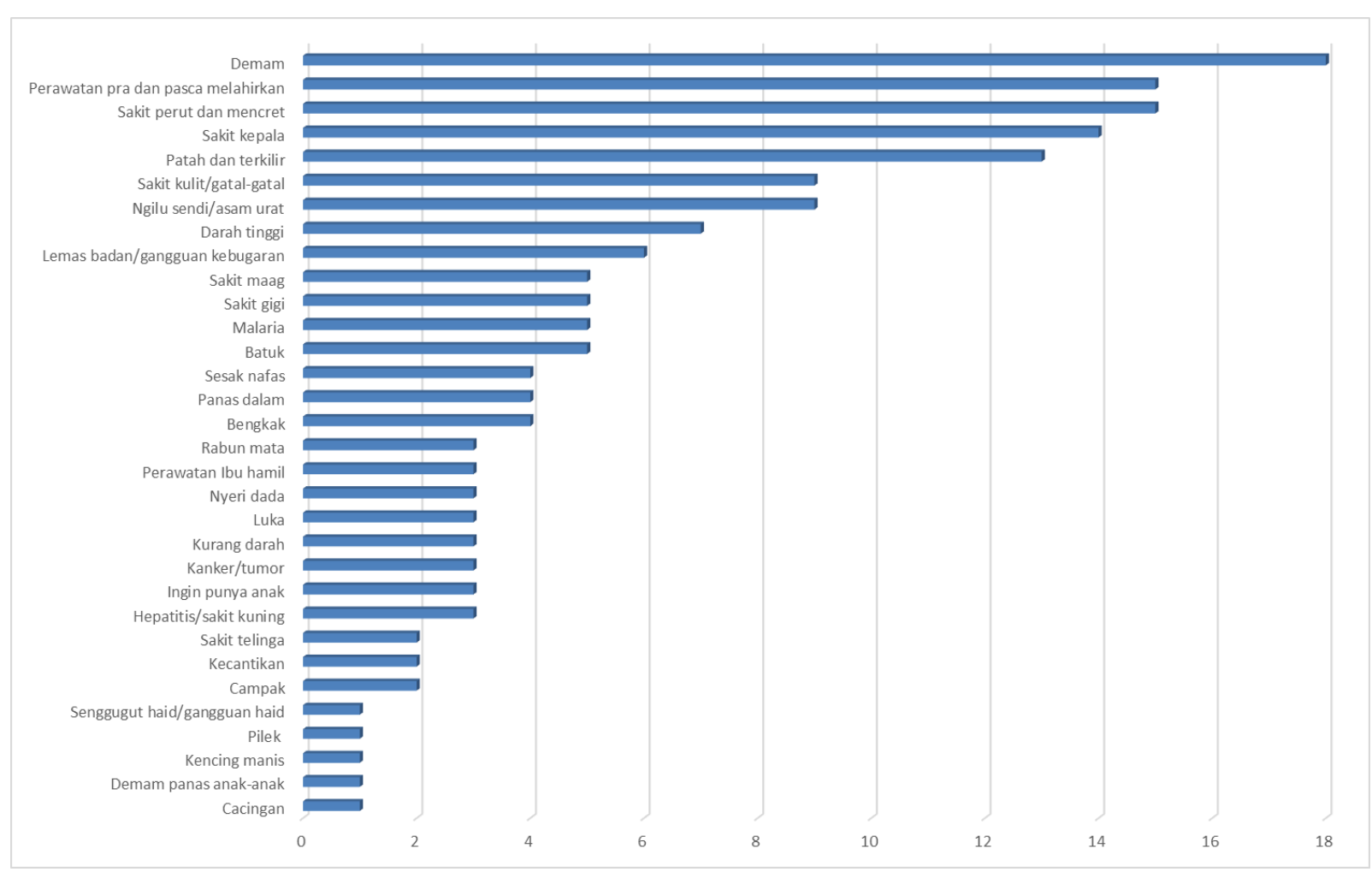

Gambar 1 Grafik penyakit yang diderita masyarakat Suku Penguluh

Tabel 4 Perbandingan manfaat tumbuhan obat berdasarkan kajian etnobotani dengan kajian literatur.

\begin{tabular}{|c|c|}
\hline \multicolumn{2}{|r|}{ Manfaat tumbuhan } \\
\hline Masyarakat & Literatur \\
\hline \multicolumn{2}{|c|}{ 1. Ageratum conyzoides (Rumput cibabi/ bandotan) } \\
\hline Obat sakit perut & $\begin{array}{l}\text { - Sebagai pengobatan luka terbakar (Mita dan Atisha 2018); Sebagai antibakteri (Mitra } \\
\text { 2013); (Astuti 2015) }\end{array}$ \\
\hline \multicolumn{2}{|c|}{ 2. Blumea balsamifera (Capo) } \\
\hline Obat ngilu sendi, pilek & - Sebagai ekspektoran untuk meredakan batuk dan pilek (Setyajati dan Kusmana 2018) \\
\hline \multicolumn{2}{|l|}{ 3. Casia alata L (Ketepeng) } \\
\hline Obat gatal-gatal & - sebagai obat penyakit kulit (Hujjatusnaini 2007) \\
\hline \multicolumn{2}{|c|}{ 4. Codiaeum variegatum (Puding telur) } \\
\hline Obat demam & - sebagai adstringen dan antibakteri (Sumadewi dan Puspitaningrum 2018). \\
\hline \multicolumn{2}{|c|}{ 5. Crynum asiaticum (Bakung) } \\
\hline \multicolumn{2}{|c|}{$\begin{array}{l}\text { Obat sakit kepala, ngilu sebagai } \\
\text { sendi }\end{array}$} \\
\hline \multicolumn{2}{|c|}{ 6. Artocarpus heterophyllus (Nangka) } \\
\hline Obat sakit perut; sakit gigi & - daun nangka memiliki aktivitas antioksidan (Nasution dan Nasution 2014) \\
\hline
\end{tabular}




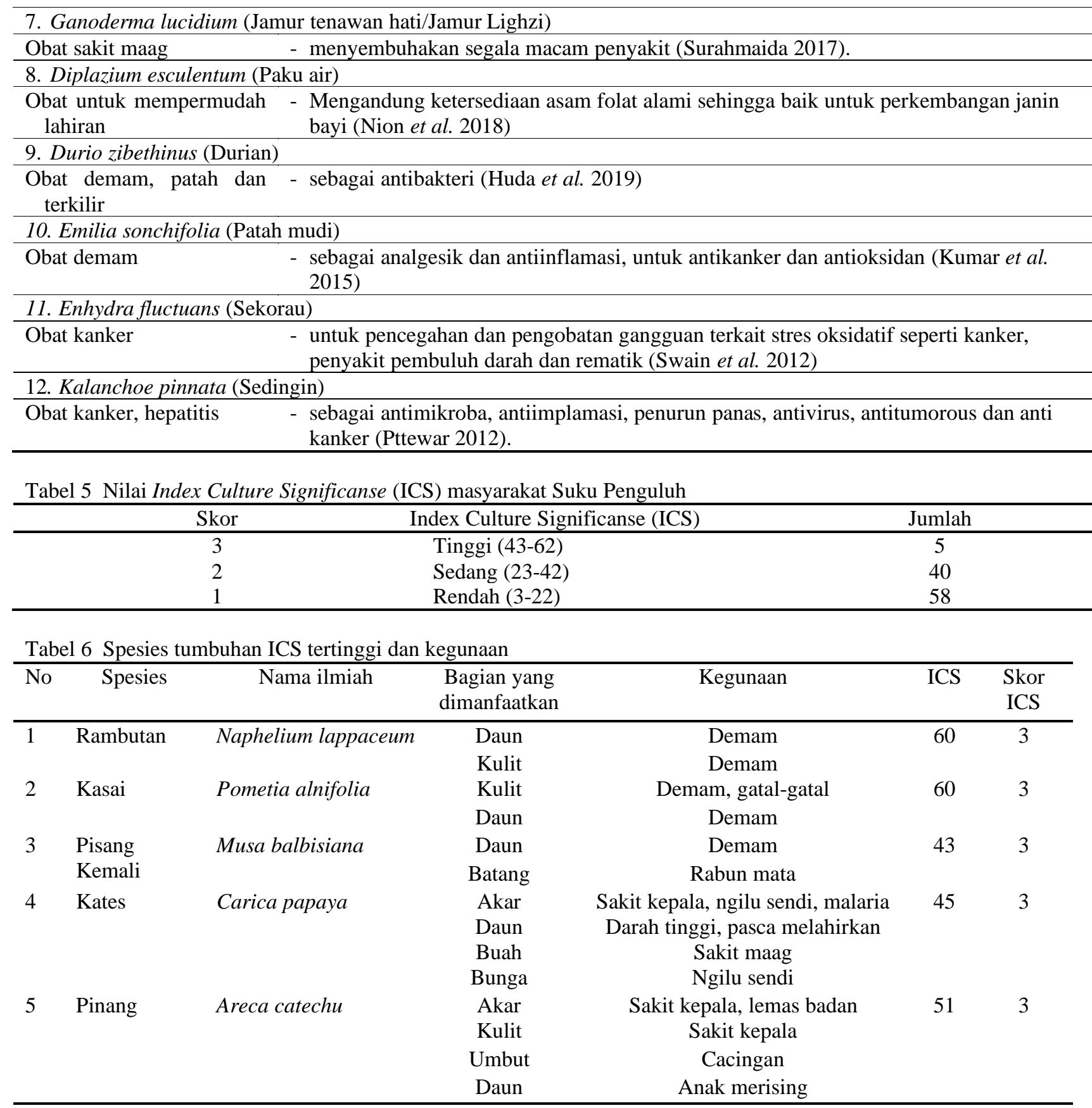

Berdasarkan hasil analisis ICS ditemukan jenis tumbuhan dari tingkat yang tinggi, sedang dan rendah. Hal tersebut mengidentifikasikan bahwa spesies-spesies tersebut sangat berperan dalam kehidupan masyarakat terhadap penyembuhan penyakit. Pengobatan penyakit demam menggunakan bentuk ramuan yaitu dengan ramuan daun rambutan, daun durian, daun dan kulit kasai direndam dalam air kemudian diremas-remas sampai keluar pati nya setelah itu diusapkan kebadan dari kanan, kiri dan tengah masing-masing tiga kali ulangan. Selain dapat dimanfaatkan sebagai obat, spesies tumbuhan tersebut dimanfaatkan masyarakat sebagai bahan pangan, bahan bangunan, dan kontruksi ringan. Intensitas penggunaan spesies yang sering, kemudahan untuk ditemukan dan memiliki peran yang besar dalam kehidupan masyarakat membuat nilai pemanfaatan tumbuhan tersebuat tinggi.

Tumbuhan yang memiliki nilai ICS rendah pada masyarakat Suku Penguluh karena intensitas penggunaan tumbuhan tersebut jarang diminati oleh masyarakat atau tingkat kesukaan masyarakat sangat rendah. Tumbuhan yang memiliki ICS rendah di antaranya ketepeng (Casia alata) dan pulai putih (Alstonia scholaris) untuk mengobati penyakit gatal-gatal. Tinggi rendahnya nilai pemanfaatan suatu tumbuhan tergantung pada seberapa besar nilai pemanfaatan dan kesukaan masyarakat terhadap suatu tumbuhan yang digunakan dalam kehidupan sehari-hari (Mirawati dan Yulianti 2014). 


\section{Strategi Konservasi dalam Pengembangan Tumbuhan Obat}

Berdasarkan hasil wawancara terhadap masyarakat Suku Penguluh di Desa Napal Melintang yang merupakan desa yang termasuk dalam Kawasan Kesatuan Pengelolaan Hutan Produksi (KPHP) Limau Unit VII Hulu tentang pemanfaatan tumbuhan obat yang dimanfaatkan oleh masyarakat perlu adanya strategi konservasi yang dilakukan untuk melindungi spesies dari kepunahan. Oleh karena itu diharuskan adanya strategi dalam pemanfaatan tumbuhan obat dalam kawasan KPH yang berbasis masyarakat dalam pelestarian tumbuhan. Strategi konservasi yang dapat dilakukan di antaranya yaitu:

1. Memaksimalkan pemakaian obat herbal.

Memaksimalkan pemakaian obat herbal oleh masyarakat dapat dilakukan dengan cara: (1) memberikan pelatihan kepada masyarakat dalam mengolah tumbuhan obat menjadi sebuah produk yang siap pakai oleh pihak KPHP; (2) penentuan dosis untuk mempercepat proses penyembuhan yang dilakukan oleh perguruan tinggi dan bekerjasama dengan masyarakat; (3) pemasaran tumbuhan obat oleh pemerintah daerah sehingga masyarakat mudah untuk menjualnya. Diaplikasikannya cara-cara di atas, masyarakat Suku Penguluh dapat memaksimalkan penggunaan tumbuhan obat lokal serta dapat mengurangi penggunaan obatobatan kimia.

2. Pengembangan budidaya.

Pengembangan model-model pemanfaatan yang tidak mengganggu populasi satu spesies dapat dilakukan dengan memperhatikan pengalaman, pengetahuan dan kearifan lokal masyarakat Suku Penguluh dalam pemanfaatan tradisional yang telah mereka lakukan secara turun temurun. Cara yang dapat dilakukan dalam pengembangan budidaya tumbuhan obat yaitu: (1) membuat demplot budidaya tumbuhan obat yang letaknya tidak jauh dari permukiman masyarakat dan (2) mebuat kelompok tani yang didominasi oleh ibu-ibu rumah tangga sebagai tanggung jawab dalam budidaya tumbuhan obat.

3. Pengembangan obat tradisional menjadi nilai ekonomi

Identifikasi tumbuhan obat dan perbandingan manfaat tumbuhan obat berdasarkan kajian etnobotani dengan kajian literatur yang telah dilakukan, dapat menjadi acuan spesies yang dapat dikembangkan menjadi obat herbal yang akan meningkatkan ekonomi masyarakat. Strategi konservasi tersebut tidak dapat berjalan jika hanya satu atau dua pihak antara masyarakat dan pihak KPHP saja yang terlibat, tetapi strategi konservasi tersebut dapat berjalan jika adanya keterlibatan beberapa pihak yang terlibat seperti masyarakat, KPHP, Perguruan tinggi, Badan POM, dan Pemerintah Daerah. Peran pihak-pihak tersebut akan sangat berpengaruh terhadap keberhasilan konservasi tumbuhan obat pada masayarakat Suku Penguluh.

\section{SIMPULAN}

Ketergantungan masyakarat Suku Penguluh akan tumbuhan obat masih tergolong tinggi. Hal tersebut dibuktikan dengan Masyarakat Suku Penguluh memiliki kemampuan dalam memanfaatkan, meramu dan mengolah tumbuhan obat untuk mengobati dan mencegah penyakit. Tumbuhan obat yang teridentifikasi sebanyak 100 spesies yang digunakan untuk mengobati 33 jenis penyakit. Spesies tumbuhan yang memiliki nilai ICS tertinggi memiliki peran besar dalam kehidupan masyarakat untuk penyembuhan penyakit yaitu rambutan (Naphelium lappaceum), kasai (Pometia alnifolia), pisang kemali (Musa balbisiana), Kates (Carica papaya) dan pinang (Areca catechu). Strategi konservasi dan pengembangan spesies tumbuhan obat yang dapat dilakukan yaitu (1) memaksimalkan pemakaian obat herbal; (2) pengembangan budidaya; (3) pengembangan tumbuhan obat menjadi nilai ekonomi.

\section{DAFTAR PUSTAKA}

Astuti H. 2015. Uji aktivitas antibakteri ekstrak etanol dan ekstrak air daun bandotan (Ageratum conyzoides L) terhadap Staphylococous aureus dan Eshericha coli. Majalah Farmaseutik. 11(1): 290293.

Auliani A, Fitmawati, Sofiyanti N. 2014. Studi etnobotani Famili Zingiberaceae dalam kehidupan masyarakat lokal di Kecamatan Siak Hulu Kabupaten Kampar. JOM FMIPA. 1(2):526-533.

Djauhariya E, Hernani. 2004. Gulma Berkhasiat Obat. Depok: Penebar Swadaya.

Huda C, Putri AE, Sari DW. 2019. Uji aktivitas antibakteri fraksi dari maserat Zibethinus folium terhadap Escherichia coli. Jurnal SainHealth. 3(1):7-14.

Hujjatusnaini N. 2007. Uji potensi ekstrak daun ketepeng (Cassia alata L) terhadap penghambatan pertumbuhan Trichophyton sp. El-Qudwah. 10 1-17

Ibrahim M, Pasya GM, Nur DM. 2013. Kehidupan Suku Penguluh Di Kecamatan Air Hitam Kabupaten Sarolangun. Jurnal Pendidikan Geografi. 1(3):1-15.

Jalius, Muswita. 2013. Eksplorasi pengetahuan lokal tentang tumbuhan obat di Suku Batin, Jambi. Biospecies. 6(1):28-37.

Kumar DG, Syafiq AM, Ruhaiyem Y. 2015. Traditional use, phytocemical and pharmacological aspects of Emilia sonchifilia (L.)DC. Int.J. Res. Ayurveda Pharm. 6(4):551-556.

Mirawat, Yulianti E. 2014. Tumbuhan berguna pada masyarakat percampuuran di Desa Lemo Utara Kecamatan Ampibabo Kabupaten Parigi Moutong Sulawesi Tengah. Biocelebes. 8(1):29-36.

Mita S, Atisha AS. 2018. Review herbal bandotan (Ageratum conyzoides L) sebagai pengobatan luka terbuka. Jurnal Farmaka Suplemen. 16(3):116-121. 
Mitra PK. 2013. Antibacterial activity of an Isolated Compound (AC-1) from the Leaves of Ageratum conyzoides Linn. Journal of Medicinal Plants Studies. 1(3):145-150.

Nasution H, Nasution MR. 2014. Pengujian antiradikal bebas difenilpikril hidrazil (DPPH) ekstrak etil asetat daun nangka (Artocarpus heterophyllus Lamk). J. Sain Dasar. 3(2):137-141.

Nion YA, Jemi R, Jagau Y, Anggreini T, Anjalani R, Damanik Z, Torang I, Yuprin. 2018. Potensi sayur organik lokal daerah rawa di Kalimantan Tengah: "manfaat dan tingkat kesukaan". EnviroScienteae. 14(3):259-271.

Pattiselano F, Manusawi J, Arobaya AYS, Manusawi H. 2015. Pengelolaan dan konservasi satwa berbasis kearifan tradisional di Papua. Jurnal Manusia dan Lingkungan. 22(1):106-112.

Pttewar SV. 2012. Kalanchoe pinnata: Phytochemical and pharmacological profil. International Journal of Phytopharmacy Review. 2(1):1-8.

Purwanto Y. 2002. The Evaluation of the Cultural Significance of plants in Ethnobotanical study of Dany-Baliem, Irian Jaya, Indonesia. Makalah disampaikan dalam International of Symposium on Land Management and Biodiversity in Southeast Asia. Organized by Hokkaido University, Sapporo Japan and Research Centre for Biology the Indonesia Institute of Science. Indonesia

Racmania RA, Hariyanti, Zikriah R, Soultan A. 2018. Studi in silico senyawa alkoloid herba bakung putih (Crinum asiaticim L.) pada penghambatan Enzim Siklooksigenase (COX). Jurnal Kimia VALENSI. 4(2):124-136.

Rahayu M, Sunarti S, Sulistiarini D, Prawiroatmodjo S. 2014. Pemanfaatan tanaman obat secara tradisional oleh masyarakat lokal Di Pulau Wawoni. Sulawesi Tenggara. Jurnal Biodiversitas. 7(3):245-250.
Salsabila PP, Zuhud EAM, Siswoyo. 2014. Pemanfaatan tumbuhan pangan dan obat oleh masyarakat di Dusun Palutungan Desa Cisantana Sekitar Taman Nasional Gunung Cermai. Media Konservasi. 19(1):146-153.

Sarwono J. 2006. Metode Penelitian Kuantitatif dan Kualitatif. Yogyakarta: Graha Ilmu.

Setyajati G, Kusmana SAF. 2018. Review artikel : Etnofarmasi, kandungan kimia dan aktivitas farmakologi batuk dari suku rimba. Farmaka. 17(1):15-20.

Sumadewi NLU, Puspitaningrum DHD. 2018. Ekstraksi dan identifikasi senyawa pada daun puring (Codiaeum variegatum) dengan pelarut air, etanol, etil asetat dan N-Heksana. Jurnal Kimia. 12(1)7073.

Surahmaida. 2017. Reviw : Potensi berbagai spesies Ganoderma sebagai tanaman obat. Journal of Pharmacy and Science. 2(1):17-21.

Swain PK, Dinda SC, Nayak DP, Kar B, Patro VJ. 2012. Antioxidant activity of Enhydra flucuans Lour areal parts. Journal of Phytotherapy and Pharmacology. 1(2):23-34.

Turner NJ. 1988. The importance of a rose : Evaluation the cultural significanse of plant in Thompson and Lillooet Interior Salish. Jornal of American Anthropology. 90(2):272-290.

Utami RD, Zuhud EAM, Hikmat A. 2019. Etnobotani dan potensi tumbuhan obat masayarakat etnik Anak Rawa Kampung Penyengat Sungai Apit Siak Riau. Media Konservaasi. 24(1):40-51.

Zuhud EAM. 2008. Potensi Hutan Tropika Indonesia Sebagai Penyangga Bahan Obat Alam Untuk Kesehatan Bangsa. Bogor: Fakultas Kehutanan Institut Pertanian Bogor. 